\title{
Suwerenność państw w międzynarodowych organizacjach integracyjnych $^{1}$
}

\begin{abstract}
Wstęp
Zagadnienie suwerenności państw w organizacjach międzynarodowych jest przedmiotem licznych badań, ale też kontrowersji i sporów naukowych oraz politycznych. Spośród licznej ich grupy, to organizacje integracyjne, jak się wydaje, najszerzej i najsilniej wkraczają w obszary, zastrzeżone wcześniej dla państw. Celem artykułu jest analiza zróżnicowanej, z punktu widzenia suwerenności, autonomii państw w organizacjach integracyjnych, w których stosowane są nowego typu rozwiązania instytucjonalne, w tym ponadnarodowe. Badania odnotowują znaczące zróżnicowanie konstrukcji organizacji, ich kompetencji oraz procesów decyzyjnych, w tym rozrastania się kompetencji i władzy organizacji. Pokazują również, że modele występujące w Europie nie znajdują uniwersalnego zastosowania. Widoczne jest odmienne podejście do suwerenności w procesach integracyjnych i organizacjach międzynarodowych na Zachodzie oraz wśród państw rozwijających się, które większą wagę przywiązują do ochrony i zabezpieczenia suwerenności w ramach organizacji.
\end{abstract}

\section{Pojęcie suwerenności}

Kwestia rozumienia suwerenności jest przedmiotem licznych opracowań i dyskusji naukowych i politycznych (Kranz, 2015, Czaputowicz, 2013, Popiuk-Rysińska, 1993). Nie wdając się w rozważania terminologiczne, w niniejszej pracy przyjmuje się, że suwerenność jest formalną i jakościową (atrybutywną) cechą państwa. Oznacza, że państwo jest odrębną jednostką geopolityczną, która formalnie sama sobą włada i nie ma nad sobą żadnej władzy. Do niej odnosi się prawnomiędzynarodowa zasada suwerennej równości. Nie określa czym jest suwerenność. Stanowi, że wszystkie państwa korzystają z praw nieodłącznie związanych z pojęciem pełnej suwerenności, wskazuje tylko na niektóre z nich i nakazuje obowiązek ich poszanowania. Wyraża zatem formalne ujęcie suwerenności, bez precyzowania jej treści. Tak ujmowana suwerenność jest idealizacyjną cechą państwa. Odnosi się do formalnej strony stosunków państwa z otoczeniem zewnętrznym, do jego prawnej odrębności

${ }^{1}$ Publikacja finansowana w ramach programu Ministerstwa Nauki i Szkolnictwa Wyższego pod nazwą „Dialog” w latach 2019-2021. 
i niezależności. Nie oddaje natomiast rzeczywistych więzi i stosunków między państwem a środowiskiem, w tym innymi uczestnikami stosunków międzynarodowych. $\mathrm{Z}$ drugiej jednak strony właściwie odzwierciedla istotę rzeczywistości międzynarodowej, a szczególnie jej atomistyczną (poliarchiczną ) strukturę. Charakteryzuje się ona tym, że jedno państwo jest umiejscowione obok drugiego, a żadne $\mathrm{z}$ nich nie ma nad sobą wyższej władzy.

Suwerenności w ujęciu formalnym odpowiada zawsze jej materialny wymiar, który nazywa się niezależnością polityczną, suwerennością de facto czy autonomią państwa. Autonomia państwa, w przeciwieństwie do suwerenności w ujęciu jakościowym, jest podatna na zmiany. Oscyluje między absolutną autonomią (samowystarczalność państwa) a prawie całkowitą zależnością i absorbcją przez inną jednostkę. Autonomia może zatem zmieniać się w pewnych granicach, jednak nie może przekroczyć dolnej nie dotykając samej istoty suwerenności. Takie ujęcie suwerenności nazywa się politycznym lub politologicznym, gdyż kładzie nacisk na praktykę polityczną, uwzględnia faktycznie zróżnicowaną skalę autonomii, w tym zjawiska uzależniania i zależności państw, formalnie suwerennych (Popiuk-Rysińska, 1995, s. 213-214).

I to właśnie ilościowy wymiar suwerenności jest obecnie przedmiotem dyskusji na temat suwerenności oraz relacji do ponadnarodowości, mogącej być rezultatem procesów integracyjnych. W dyskusji tej można wyróżnić dwa skrajne stanowiska. Po pierwsze, suwerenność utożsamiana jest z idealnym wzorcem autonomii, a najczęściej z pełną autonomią wewnętrzną i całkowitą swobodą działania w stosunkach międzynarodowych. Zwolennicy tego podejścia odwołują się do koncepcji suwerenności Bodina i Hobbesa oraz do zakresu autonomii państw z okresu tzw. anarchii suwerenności (koniec XV w. - początek XX w.). Twierdzą, że w tamtych czasach państwa dysponowały prawdziwą suwerennością, teraz zaś - w okresie narastania współzależności oraz rozwoju współpracy międzynarodowej - następuje erozja suwerenności, jej schyłek. W tym nurcie mieszczą się też poglądy głoszące, że prawdziwymi suwerenami są mocarstwa, zwłaszcza USA, które mają największe możliwości i swobodę działania w płaszczyźnie międzynarodowej. Można zatem powiedzieć, że w tym przypadku utożsamia się formalny międzynarodowy status państwa ze stanem faktycznym, absolutyzując suwerenność.

Według drugiego stanowiska, suwerenności nie należy łączyć z jakimkolwiek idealnym wzorcem autonomii. Nigdy bowiem w historii żadne państwo taką autonomią nie dysponowało. Koncepcja suwerenności absolutnej nie nadaje się do opisu aktualnych stosunków, ani też nie oddaje wiernie skali autonomii państwa w żadnym okresie historycznym. Trzeba raczej przyjąć, że w różnych okresach historycznych i warunkach zakres autonomii państwa zmieniał się pod wpływem oddziaływania wielu czynników. Zmiany te miały charakter zarówno żywiołowy, jak i świadomy, zachodzące pod wpływem samych państw, często za ich zgodą i przyzwoleniem. Można zatem skonstatować, że w tych sytuacjach państwa same decydowały o zakresie swojej autonomii, same dokonywały reinterpretacji suwerenności. Inaczej mówiąc, państwa zawsze poruszały się na pewnym continuum autonomii i nie utożsamiły jej z jakimś absolutnym wzorcem. W zależności od różnych uwarunkowań i czynników, poszerzały lub zawężały granice autonomii. Można też zauważyć w tym obszarze pewną prawidłowość, a mianowicie, suwerenność ( status formalny) była zawsze tytułem słu- 
żącym ochronie i rozszerzaniu skali autonomii, ale też jej dobrowolnemu ograniczaniu, uogólniając kontroli przez państwo zakresu jego autonomii. Trzeba też dodać, że państwa, uczestnicząc w stosunkach międzynarodowych, starają się uzyskać międzynarodową legitymizację dla własnej koncepcji suwerenności, tj. pożądanej i optymalnej skali autonomii (Popiuk-Rysińska, 1995, s. 213-214). Można zakładać, że z takim zjawiskiem mamy do czynienia w organizacjach międzynarodowych.

\section{Ujęcia międzynarodowej organizacji integracyjnej}

Kształtowanie się organizacji integracyjnych nastąpiło dopiero po II wojnie światowej. Pierwszą z nich była Europejska Wspólnota Węgla i Stali (1952), której powstanie zapoczątkowało proces integracji europejskiej, zakończony powstaniem UE (2009). W latach sześćdziesiątych XX w. została utworzona liczna grupa regionalnych organizacji integracyjnych, głównie z udziałem państw rozwijających się, w Ameryce Łacińskiej, na Bliskim Wschodzie oraz w Afryce. Były one często wzorowane na Wspólnotach Europejskich, a większość z nich została rozwiązana. Kolejna fala regionalizmu wystąpiła po zakończeniu zimnej wojny, kiedy powstała liczna grupa ugrupowań regionalnych. Kolejna nowa fala rozwoju regionalizmu wystąpiła po zakończeniu zimnej wojny. Obecnie istnieje prawie 30 aktywnych lub nieaktywnych porozumień integracyjnych (Chung-in Moon, 2016), w tym Afrykańska Wspólnota Gospodarcza, Wspólnota Andyjska, ASEAN, Wspólny Rynek Ameryki Środkowej, Wspólnota Karaibska i Wspólny Rynek (CARICOM), Wspólny Rynek Afryki Środkowej, Rada Współpracy Zatoki Perskiej, Wspólny Rynek Ameryki Środkowej (CACM), Wspólnota Karaibska (CARICOM), Wspólnota Gospodarcza Państw Afryki Zachodniej (ECOWAS), Wspólnota Rozwoju Afryki Południowej. Najwyższy poziom integracji osiągnęła UE, będąca na etapie unii walutowej i gospodarczej oraz prowadząca wspólne polityki w określonych obszarach.

Powstawanie tych organizacji świadczy o tym, że w przypadku państw, ich włączanie się w procesy integracji nie ma charakteru żywiołowego, ale jest wyrazem świadomego działania, służącego realizacji interesów narodowych. Dla celów tej pracy definiuje się organizację międzyrządową jako wielostronny celowy związek państw powstały na podstawie zawartego między nimi porozumienia i wyposażony w system stałych organów. Organizacje międzynarodowe są zróżnicowaną grupą podmiotów. Można je systematyzować według różnych kryteriów, w tym najważniejsze, to: zakres członkostwa (powszechne, regionalne, międzykontynentalne), zakres przedmiotowych kompetencji (wszechstronne, wyspecjalizowane), stopień „władzy” (koordynacyjne, ponadnarodowe), sposób realizacji celów (koordynacja/ współpraca, integracja) (Popiuk-Rysińska, 2012, s. 21-24; Menkes, Wasilkowski, 2017, s. 167-212). Każdą organizację można opisać, biorąc je pod uwagę. Tak więc, z punktu widzenia tematu, teoretycznie rzecz ujmując, przedmiotem dalszych badań mogą być organizacje integracyjne powszechne lub regionalne albo integracyjne koordynacyjne lub ponadnarodowe.

$\mathrm{W}$ praktyce organizacje integracyjne występują tylko $\mathrm{w}$ grupie organizacji regionalnych. Nie istnieją obecnie organizacje integracyjne powszechne. Tak więc, przed- 
miotem niniejszego artykułu będą $\mathrm{w}$ istocie regionalne organizacje integracyjne, $\mathrm{w}$ tym ponadnarodowe, bowiem nie każda integracja przybiera formę ponadnarodową.

Ponadnarodowość jest cechą organizacji, odnoszącą się do jej „władzy”, którą można rozumieć jako zdolność i siłę oddziaływania na środowisko zewnętrzne, w tym na państwa członkowskie (Ruszkowski, 2010). Na podstawie tego kryterium wyróżnia się organizacje koordynacyjne, w których dominuje czynnik międzyrządowy oraz ponadnarodowe. Podział ten pojawił się wraz z powstaniem Wspólnot Europejskich, które zaczęto określać jako ponadnarodowe. Określenie to miało wskazywać, że państwa członkowskie przekazały na rzecz Wspólnot określone kompetencje w stopniu niewspółmiernie większym niż w innych organizacjach (Kranz, 2013). Wspólnoty/Unia dysponują samodzielnymi uprawnieniami władczymi o charakterze prawodawczym, wykonawczym i kontrolnym w wyznaczonym im przez państwa obszarze spraw. W praktyce ponadnarodowość Wspólnot/Unii jest skutkiem kumulacji w jej ramach takich cech jak: prawo do wydawania aktów prawnych wiążących państwa i obowiązujących bezpośrednio na ich terytoriach, podejmowanie przez organy międzyrządowe decyzji wiążących większością głosów, wyższość prawa wspólnotowego nad prawem krajowym, ustanowienie organów niezależnych od państw, kontrolujących przestrzeganie prawa wspólnotowego, prawo organizacji do występowania w stosunkach zewnętrznych ze skutkiem prawnym dla państw, upodmiotowienie osób fizycznych. Uprawnienia władcze Unii są realizowane w obszarach „uwspólnotowionych”, natomiast nie obejmują wszystkich dziedzin działania Unii, w tym wspólnej polityki zagranicznej i bezpieczeństwa oraz obrony.

Poza Unią niektóre z powyższych rozwiązań są stosowane również $\mathrm{w}$ innych organizacjach, ale nigdy w tak dużym zakresie. Niewątpliwie, organizacje te dysponują znacznie mniejszymi zdolnościami oddziaływania na państwa członkowskie. W związku z tym całą tę grupę państw zwyczajowo zalicza się do koordynacyjnych. Trudno jest jednak określić precyzyjnie cechy takich organizacji, ponieważ obserwujemy wśród nich znaczne zróżnicowanie stopnia władzy. Nazywanie ich koordynacyjnymi jest zatem uproszczeniem i ma znaczenie umowne. Biorąc pod uwagę te zastrzeżenia, można powiedzieć, że organizacja koordynacyjna nie dysponuje samodzielnymi kompetencjami wobec państw. Stanowi ona forum uzgadniania stanowisk i polityk członków, służy koordynacji ich działań i tylko w ograniczonym zakresie może oddziaływać na rządy. Nie ma środków wkraczających bezpośrednio w przestrzeń władczą państw, które zastrzegają sobie prawo ostatecznej decyzji w obrębie spraw wchodzących w zakres kompetencji organizacji (Popiuk-Rysińska, 2012, s. 23-24).

Aby uniknąć uproszczeń, jakim obarczony jest ów dychotomiczny podział, Wojciech Morawiecki zaproponował, aby „określić krańcowe sytuacje, w których władza organizacji międzynarodowej osiąga najniższy lub najwyższy poziom, i odpowiednio sklasyfikować organizacje jako zbliżające się do jednego lub drugiego krańca" (Morawiecki, 1987, s. 87).

W zbliżony sposób organizacje charakteryzują Tobias Lenz oraz Gary Marks. Uznają, że organizacje regionalne można umieścić na „spectrum od międzyrządowości do ponadnarodowości”, co generalnie koresponduje z rozróżnieniem między współpracą a integracją. Kiedy państwa członkowskie w organizacji regionalnej kontrolują proces decyzyjny, implementację i rozwiązywanie sporów, możemy mówić o między- 
rządowości”. Odwrotnie, każde odstępstwo od monopolu państwa w tym zakresie jest ruchem do ponadnarodowości. Ten podział jest odzwierciedleniem dwóch przeciwstawnych wymiarów modeli instytucjonalnych, nazwanych ,pooling” i ,delegation”. Termin ,pooling” oznacza w tym kontekście ,współudział” w procesie decyzyjnym, bowiem jest on określany jako taka sytuacja, w której państwa transferują na rzecz organizacji pewne kompetencje, w zakresie których podejmują decyzję kwalifikowaną większością głosów, a więc uczestniczą w procesie podejmowania decyzji, ale nie są w stanie go kontrolować (Keohane, Hoffman, 1991, s. 7; Lenz, Marks, s. 514)². „Delegowanie”, przeciwnie zakłada ,warunkowe przekazanie kompetencji od mocodawcy do agenta, który daje drugiemu władzę do działania w imieniu tego poprzedniego" (Hawkins i in., 2006, s. 7; Lenz, Marks, s. 514)³. Państwa członkowskie delegują kompetencje, zachowując kontrolę nad agentem. Wskutek tego, delegowany agent korzysta z pewnego stopnia autonomii, który może wykorzystać dla realizacji swoich celów (Lenz, Marks, 2016, s. 514-517).

Organizacje, które mają kompetencje wyłączne, przekazane im przez państwa, mogą uzyskać status autonomicznych uczestników stosunków międzynarodowych oraz podmiotów prawa międzynarodowego. Dla określenia podmiotowości organizacji w nauce stosowane są również inne określenia, takie jak organizacja - aktor lub „międzynarodowe aktorstwo” („International actorness”). „Międzynarodowe aktorstwo" jest rozumiane jako ,zdolność do formułowania wspólnej zewnętrznej polityki oraz obrony interesów państw członkowskich wobec zewnętrznych aktorów”. Taka sytuacja występuje wówczas, gdy w procesie decyzyjnym przeważa ponadnarodowość nad międzyrządowością. Jest to konsekwencja wysokiego poziomu współdecydowania, który może być zróżnicowany, zależnie od dziedziny, np. w przypadku UE jej podmiotowość jest silna w sprawach handlowych, natomiast niska w zakresie polityki zagranicznej i bezpieczeństwa (Lenz, Marks, s. 526-527). Badania i studia porównawcze UE i ASEAN wskazują również, że kwalifikowana większość głosów ułatwia kształtowanie się ,aktorstwa”, natomiast jednomyślność przeszkadza, hamuje. Innym ważnym czynnikiem ,aktorstwa” jest istnienie ponadnarodowego negocjatora, który występuje w imieniu organizacji (Lenz, Marks, s. 526-527).

Natomiast określeniem organizacja - aktor posługują się Jerzy Menkes i Andrzej Wasilkowski, którzy wyróżniają dwie grupy organizacji, organizację - aktora w przeciwieństwie do organizacji - forum. Organizacja - aktor jest „wyposażona przez członków we własne (niezależne od członków) kompetencje w stosunkach międzynarodowych i w stosunku do członków, w zakresach innych (niż własne) kompetencje wykonuje funkcje organizacji - forum rozwiązywania problemów we współpracy między członkami oraz organizowania ich stosunków" (Menkes, Wasilkowski, s. 172). Łączą tego typu organizacje z ,regionalnymi organizacjami integracyjnymi”, zwracając uwagę, że termin „międzynarodowa organizacja nie jest tylko terminem ze sfery nauki czy praktyki, ale również ,terminem języka prawnego i posługują się

2 Termin ,pooling”, jaki stosują w badaniach Lenz i Marks, pochodzi z pracy Keohane'a i Hoffmanna (1991), do którego się odwołują. Jest trudny do przetłumaczenia, stąd propozycja swobodnego thumaczenia go jako „współudział”, co jest bliskie treści definicji.

${ }^{3}$ Lenz i Marks definiując pojęcie ,delegowanie” odwołują się do publikacji wspólnej kilku autorów z udziałem Hawkinsa (2006, s. 7). 
nim państwa np. w umowach międzynarodowych, w których chcą umożliwić Unii, czy innym organizacjom (np. Mercosur, Wspólnota Andyjska) jako samodzielnym podmiotom przystąpić do umowy międzynarodowej, w tym umowy będącej statutem organizacji międzynarodowej. Definicje takie zawierają między innymi: Ramowa Konwencja Narodów Zjednoczonych w sprawie klimatu, Konwencja o różnorodności biologicznej oraz Konstytucja FAO (ibidem). W tej ostatniej, zgodnie z art. 2 ust. 4 organizacja regionalna, aby uzyskać członkostwo „musi być utworzona przez suwerenne państwa, z których większość jest członkami Narodów Zjednoczonych, i której jej państwa członkowskie przekazały (transfered) kompetencje w zakresie spraw wchodzących w zakres kompetencji organizacji, włączając kompetencję (the authority) do podejmowania decyzji wiążących jej państwa członkowskie w odniesieniu do tych spraw". W definicji tej z jednej strony zwraca się uwagę na suwerenność państw założycielskich organizacji, z drugiej na jej kompetencje pochodne, nadające jej podmiotowość prawnomiędzynarodową, będące skutkiem transferu przez państwa swoich kompetencji, jak również prawo do podejmowania decyzji wiążących państwa (Menkes, Wasilkowski, s. 174).

Tak jak w przypadku władzy organizacji, tak też integracji, organizacje można sytuować na continuum, od najwyższego do najniższego poziomu integracji. W przypadku organizacji integracyjnych, integracja nie jest celem samym w sobie, ale środkiem dla osiągania innych celów, zwykle rozwoju gospodarczego. Tylko w nielicznych organizacjach, zwłaszcza w przypadku Unii Europejskiej, jej państwa członkowskie w Preambule do Traktatu o Unii Europejskiej wyraziły „Zdecydowanie kontynuować proces tworzenia coraz ściślejszego związku między narodami Europy, w którym decyzje są podejmowane jak najbliżej obywateli, zgodnie z zasadą pomocniczości" oraz postanowiły rozważyć dalsze „,przedsięwzięcia na rzecz rozwoju integracji europejskiej" (Traktat o Unii Europejskiej, 2009). Można to zinterpretować jako wyraz woli dalszego pogłębiania integracji.

Poza Unią organizacje integracyjne inicjują lub rozwijają integrację w określonych dziedzinach, najczęściej gospodarczej. Większość z nich znajduje się dopiero w początkowej fazie integracji gospodarczej, która przejawia się w czterech głównych formach, od najmniej do najwyżej zaawansowanej, tj. strefy wolnego handlu, unii celnej, wspólnego rynku oraz unii gospodarczej.

\section{Między międzyrządowością a ponadnarodowością}

Można zauważyć, że suwerenność jako pojęcie jest uznawane za bardzo wartościowe i przydatne, stosowane dosyć swobodnie, także po to, by nadać legitymizację nowym pomysłom powiększenia władzy organizacji i ograniczania na ich rzecz kompetencji państw. Przykładem tego są dwa zbieżne stanowiska odnośnie do nadania suwerenności UE, jeden wyrażający stanowisko Komisji Europejskiej, drugi - prezydenta Francji. W obu przypadkach cechy suwerenności przypisuje się UE. Ideę suwerenności europejskiej zaprezentował 26 września 2017 r. w Paryżu prezydent Francji Emmanuel Macron w wystąpieniu pod znamiennym tytułem „Inicjatywa dla Europy. Przemówienie za Europą suwerenną, zjednoczoną, demokratyczną", w którym uznał 
suwerenność organizacji za uzupełniającą suwerenność narodową. Przyjmując takie stanowisko, opierał je na negatywnej ocenie państwa, które nie jest w stanie podołać wyzwaniom współczesnego świata. Twierdził, że ,Tylko Europa może [...] zagwarantować prawdziwą suwerenność, czyli naszą zdolność funkcjonowania we współczesnym świecie, aby bronić naszych wartości i interesów" (Macron, 2017; Kaczyński, 2019).

W podobnym tonie brzmiało Orędzie o stanie Unii Jeana-Clauda Junckera z 2018 roku, zatytułowane „Czas europejskiej suwerenności”, w którym Juncker mówił między innymi, że „Geopolityka uczy nas, że przyszedł czas na europejską suwerenność, czas, aby Europa wzięła odpowiedzialność za swe losy, [...] Europa powinna stać się niezależnym podmiotem stosunków międzynarodowych. Europejska suwerenność wynika z niepodległości poszczególnych państw członkowskich. Nie zastępuje tego, co jest właściwe narodom [...] Dzielenie się suwerennością powinno wzmacniać każde państwo narodowe" ( Juncker, 2018)

$\mathrm{W}$ wypowiedziach tych przewija się idea integracji ponadnarodowej z nowym kształtującym suwerenem, jakim ma stać się UE. Jednak, integracja ponadnarodowa nie jest i nie była jednym modelem integracji i współpracy państw. W praktyce były stosowane różne jej formy, mające zróżnicowany wpływ na autonomię integrujących się państw i nie zakładające ,,podziału” lub „scalania” suwerenności. Historia integracji w Europie, jak również poza nią, wskazuje na różne modele zarządzania - międzyrządowy i ponadnarodowy oraz formy mieszane (hybrydowe), zawierające elementy ponadnarodowości i międzyrządowości. W przypadku modelu międzyrządowego, autonomia państw nie doznaje uszczerbku, bowiem decyzje są podejmowane przez przedstawicieli państw. Natomiast w drugim przypadku, ponadnarodowe rozwiązania mogą tę autonomię ograniczać. Rzadko przyjmowane są rozwiązania klarowne, przemyślane i łatwe do opisania. Często mamy do czynienia z połączeniem różnych form współpracy i integracji, trudnych do zdefiniowania. Tak jest też w przypadku Unii Europejskiej, której konstrukcja daje szerokie i zróżnicowane możliwości interpretacyjne. W zależności od ujęcia czy podejścia teoretycznego uznaje się ją za organizację międzynarodową, wspólnotę polityczną, formę regionalizmu, system wielopoziomowego zarządzania czy też imperium (Czaputowicz, 2018, s. 218).

Ujęcia te różnią się stosunkiem do suwerenności oraz określeniem relacji między instytucjami, w tym międzyrządowymi i ponadnarodowymi (ibidem). Generalnie ujmując, z jednej strony Unia jest ujmowana w kategoriach tradycyjnej międzyrządowości, co jest zbliżone do teorii neorealizmu w badaniach stosunków międzynarodowych. Według tego ujęcia, którego wyrazicielem jest między innymi Stanley Hoffman, to państwa, a nie ponadnarodowe organy, jak Komisja Europejska, są nadal głównymi podmiotami w Unii. Państwa mają odrębne interesy w najważniejszych dziedzinach (np. bezpieczeństwo i sprawy zagraniczne), dlatego będą opierać się utracie władzy decyzyjnej na rzecz ponadnarodowych podmiotów dużo bardziej, silniej niż w przypadku ,low politics”, jak handel czy gospodarka (Hoffmann, 1966). Unia jest tu ujmowana jako organizacja międzynarodowa, ewentualnie specyficzna organizacja międzynarodowa. W ujęciu Unii jako imperium zwraca się uwagę na dominację najsilniejszych państw w organizacji, które kontrolują instytucje ponadnarodowe i transnarodowe. W związku z tym można powiedzieć, że w tym przypadku zwiększa 
się swoboda działania i pozycja państw najsilniejszych, natomiast pozostałych ulega redukcji (Czaputowicz, 2018, s. 219).

Z drugiej strony sytuują się teorie, które odchodzą od państwowocentrycznej wizji świata, a część, ogólnie rzecz biorąc zakłada stopniową deetatyzację (odpaństwowienie) świata, a integrację ujmują jako proces prowadzący do utworzenia nowych ośrodków władzy na poziomie ponadnarodowym lub jej rozproszenia na wielu poziomach. Należą do nich głównie tzw. teorie liberalne (funkcjonalizm, neofunkcjonalizmu, transakcjonizm) (Czaputowicz, 2018). Ogólnie ujmując zakładają one, że pod wpływem narastających współzależności państwa nie są w stanie skutecznie zaspokajać potrzeb społecznych, stąd będą one lepiej realizowane w ramach innych wspólnot (Mitrany, 1975, s. 89). Będzie następował transfer funkcji państwa na poziom międzynarodowy pod wpływem różnych czynników, w tym, według funkcjonalistów, samoczynnego procesu rozprysku (efekt spill over). Oznacza to, że coraz szersze funkcje będą powoli i systematycznie „odseparowywane” od państw i przenoszone na poziom międzynarodowy. Jednocześnie jednostki i grupy społeczne będą „przenosić” lojalność z państw na organizacje międzynarodowe. Funkcjonaliści wierzyli, że istniejące już organizacje wyspecjalizowane (techniczne), będą stanowić bazę dla utworzenia takiego rządu (Mitrany, 1966, s. 19, 98, 133).

Powyższe interpretacje w najbardziej skrajnych wersjach nie sprawdziły się w praktyce, zwłaszcza w odniesieniu do skutków rozwoju współpracy funkcjonalnej, to jednak ten model wyjaśniania, w formie bardziej umiarkowanej, dominuje w badaniach nad Wspólnotami Europejskimi/Unią Europejską. Bez wątpienia pozwala on wyjaśnić szereg (nie wszystkie!) aspektów ich rozwoju, zwłaszcza rozszerzania się kompetencji organizacji w wyniku efektu „rozprysku”. Trzeba jedna zgodzić się z krytykami neofunkcjonalizmu, że polityczne procesy „rozprysku” przebiegają powoli i są raczej niejednorodne. Jak pokazują badania, stosunek grup interesów do Wspólnot nie jest stały i zmienia się od poparcia do poważnej opozycji. Należy też zwrócić uwagę na zasadną krytykę ze strony realistów, którzy zwracają uwagę na rolę czynnika rządowego, interesów państwowych i tradycyjnych metod dyplomacji w procesach decyzyjnych.

Wskazując na powyższe teorie integracji można zauważyć, że były one ściśle powiązane z genezą i ewolucją Wspólnot Europejskich, nie pasowały do wyjaśniania integracji w innych regionach, ponieważ ,ich założenia dotyczące warunków startowych takich jak pluralistyczne interesy polityczne czy gospodarcza współzależność nie były do zastosowania poza Zachodem" (Acharya, 2016, s. 115). Co więcej, eksperymenty w regionalnej integracji poza Europą nie powiodły się. Wiele międzynarodowych regionalnych organizacji integracyjnych zostało rozwiązanych w latach 70. Poza różnicami o charakterze historycznym, politycznym i gospodarczym, ważną rolę odgrywały też zróżnicowane siły motywacyjne, np. neofunkcjonaliści zakładali, że powstanie nowe centrum ponadnarodowej władzy, które zastąpi „przestarzałe” i zachowujące się konfliktowo państwo (Hoefnagels, 1981, s. 15). „EWG była generalnie postrzegana jako projekt dla okiełznania nacjonalizmu i ograniczenia suwerenności państwa; niezachodni regionalizm był inspirowany przez dokładnie opozycyjną motywację, wzmocnić nacjonalizm i ochronić suwerenność po wiekach kolonialnych rządów. Ta genetyczna odmienność wyjaśniała i nadal wyjaśnia, 
dlaczego model UE nie był w stanie znaleźć rezonansu w niezachodnim świecie" (Acharya, 2016, s. 115). Przekazywanie kompetencji na rzecz organizacji, jak również powiększanie jej władzy, jak to miało miejsce w Europie, nie zgadzało się z dążeniami państw, które wyzwoliły się z niewoli kolonialnej i wysoko ceniły suwerenność, niezależność oraz zasadę nieingerencji w sprawy wewnętrzne. Poza tym, na obszarach poza Zachodem, współzależności między państwami nie były tak silne, by wymuszać integrację i wywoływać efekt spill over. Tutaj decyzję o utworzeniu ugrupowania integracyjnego podejmowali politycy, którzy często częściej niż na Zachodzie korzystali przy podejmowaniu decyzji z nieformalnych instrumentów, przedkładając consensus nad sformalizowane procesy decyzyjne w ramach organizacji, chroniąc swoją autonomię (ibidem).

Procesy integracji regionalnej mogą zachodzić w różnych formach instytucjonalnych. Z jednej strony, w przypadku silnych powiązań, występuje wysoki poziom instytucjonalnej integracji przez wspólnie podzielane normy, zasady, reguły, procedury decyzyjne, które ograniczają autonomię państw członkowskich. Najlepszym przykładem jest UE, która powstała w drodze ewolucji od strefy wolnego handlu do unii gospodarczej i walutowej. Integracja wyzwoliła efekt spill over, w rezultacie którego integracja rozszerzyła się na inne obszary, pozagospodarcze. Na drugim biegunie sytuuje się luźna forma integracji, bez instytucji, z nieformalnymi mechanizmami konsultacji oraz środkami budowania consensusu (APEC, NAFTA). Pomiędzy nimi występuje liczna grupa organizacji o zróżnicowanym stopniu integracji i ponadnarodowości.

Przeprowadzone przez Lenza i Marksa badania 27 organizacji regionalnych o wszechstronnych kompetencjach, w których znalazły się także organizacje integracyjne, pokazały, że stanowią one niezwykle zróżnicowaną mieszankę ,współudziału” i „delegowania”, ale „delegowanie” jest bardziej rozpowszechnioną formą niż „współudział”. Modelowa kategoria to organizacja z niskim poziomem „współdecydowania” oraz wysokim poziomem ,delegowania”. Wiele organizacji ma stosunkowo wysoki poziom obu wskaźników, w tym Wspólnota Andyjska, Wspólnota Wschodnioafrykańska, najwyższy - Unia Europejska. Oba wymiary na niskim poziomie odnotowano w organizacjach takich jak: Mercosur, Rada Nordycka, Szanghajska Organizacja Współpracy, które są bliższe międzyrządowemu modelowi współpracy międzynarodowej. Jakkolwiek między organizacjami z wysokim/wysokim i niskim/ niskim wskaźnikiem, „delegacji” ma tendencję do szerszego rozprzestrzeniania się niż „współdecydowanie”. Przykładem organizacji, która ma oba wskaźniki niskie jest Szanghajska Organizacja Współpracy (Lenz, Marks, s. 514).

Według autorów badań ,współudział jest raczej wyjątkiem” niż zasadą, a jego poziom pozostaje raczej stabilny w czasie. Wyjątkiem są organizacje europejskie, UE i Rada Europy, w innych, jeśli współdziałanie występuje, to ogranicza się do decyzji budżetowych i niektórych merytorycznych (np. Wspólnota Andyjska, Unia Gospodarcza i Monetarna Afryki Środkowej) (Lenz, Marks, s. 514-515).

W przeciwieństwie do tego, proces delegowania istotnie się rozwija. Obejmuje on rozszerzanie się kompetencji sekretariatów, organów międzyparlamentarnych oraz organów rozwiązywania sporów. „Obecnie, większość organizacji regionalnych ma sekretariat (współ)odpowiedzialny za ustalanie programu, mechanizm rozwiązywania 
sporów, który ciszy się pewną niezależnością od państw członkowskich oraz jedno lub więcej ciał konsultacyjnych złożonych z aktorów niepaństwowych" (Lenz, Marks, s. 515). Równocześnie występują duże różnice między organizacjami. Unia jest wyjątkiem z zakresie głębokości i zasięgu delegacji. Nieliczne organizacje akceptują inicjatywę programową sekretariatu, jak w przypadku Komisji w UE. Tylko sześć przyznaje parlamentom prawo udziału w procesie decyzyjnym (Wspólnota Afryki Wschodniej), większość tego typu organów ma funkcje doradcze. Największa delegacja nastąpiła na rzecz organów sądowniczych i niezależnych mechanizmów kontroli, co objęło 12 organizacji. Jednak większość organizacji polega na mechanizmach międzyrządowych. Organizacje te mają zazwyczaj trójstopniową strukturę organów, w której naczelnym organem decyzyjnym jest organ międzyrządowy typu walne zgromadzenie (Lenz, Marks, s. 515-516).

W przypadku „delegacji” badano stopień, w jakim państwa transferują kompetencje na pięć typów organów: sekretariaty generalne, ciała konsultacyjne, zgromadzenia, organy wykonawcze, sądy. Wyciągnięto generalny wniosek, że rozmiar delegacji jest funkcją liczby organów niepaństwowych oraz liczby obszarów decyzyjnych, w których odgrywają one jakąś formalną rolę. W przypadku mechanizmów załatwiania sporów, delegacja jest funkcją zakresu, w jakim organ sądowy jest niezależny od kontroli państw członkowskich, podejmuje decyzje wiążące oraz dostępu do niego aktorów niepaństwowych. Niski poziom delegacji występuje w Radzie Współpracy Zatoki Perskiej, gdzie sekretariat proponuje budżet, może proponować podjęcie decyzji programowych oraz istnieje Komisja do spraw rozwiązywania sporów, która wydaje niewiążące werdykty. Na poziomie średnim sytuuje się Organizacja Państw Wschodnich Karaibów, w której sekretariat pełni funkcje wykonawcze, proponuje budżet, ma kompetencje, w zakresie inicjatywy programowej, natomiast stały Sąd Najwyższy Wschodnich Karaibów ma automatyczne prawo do przeglądu oraz i wydawania wiążących decyzji z bezpośrednim skutkiem. Do kategorii najwyższej należy Unia Europejska, z instytucjami niezależnymi od państw, Komisja Europejska, Parlament, Trybunał Sprawiedliwości (ibidem).

Ogólnie rzecz biorąc, badania pokazują, że poziom delegacji i współdecydowania w organizacjach pozaeuropejskich jest znacząco niższy niż w UE. Ma to związek $\mathrm{z}$ odmienną genezą procesów integracji w Europie i świecie niezachodnim. Inny jest też model integracji, jak również jej geneza. Jak wskazuje Amitav Acharya, „Niezachodnie regionalne grupy są generalnie bardziej przywiązane do suwerenności, ukazując dużo bardziej większe uzależnienie od zasady nieinterwencji [...] charakteryzują się mniejszą biurokracją i ukazują większe preferencje dla nieformalnych procesów, consensus (jako przeciwieństwo głosowania większościowego) jako sposobu podejmowania decyzji oraz jego niewiążące decyzje" (Acharya, 2016, s. 114-115). Warto też wskazać, że w statutach tych organizacji zazwyczaj na pierwszym miejscu wymienia się zasadę ochrony i poszanowania suwerenności oraz nieingerencji w sprawy wewnętrzne. Ponadto instrumentem ochrony suwerenności jest zasada consensusu przy podejmowaniu decyzji przez wszystkie organy międzyrządowe, np. we Wspólnocie Rozwoju Afryki Południowej oraz Wspólnocie Gospodarczej Państw Afryki Środkowej. W wielu przypadkach tego rodzaju decyzje są uznawane za wiążące prawnie, ale zawsze wymagają zgody państwa. Należy 
jednak wskazać, że w ramach tej tendencji, występują różnice między organizacjami i regionami. Generalnie tendencja jest taka, że kompetencje organizacji międzynarodowych rozszerzają się pod wpływem wzrostu współzależności międzynarodowych, co może skutkować zmianą procesów decyzyjnych od consensusu do większości, jak również sformalizowaniem procesów decyzyjnych. Wynikiem tego może być ograniczenie autonomii państw w ramach organizacji.

Lenz i Marks zwracają też uwagę na znaczenie nieformalnych instytucji, które zapewniają państwom kontrolę nad organizacją, zwłaszcza silniejszym państwom. W przypadku „współudziału”, jest widoczna tendencja do unikania narzucania decyzji innym i poszukiwania consensusu. ,Jednakże, istnieją wiarygodne dowody teoretyczne i empiryczne, że zasada formalnej większości w podejmowaniu decyzji ogranicza nieformalne podejmowanie decyzji przez consensus. $Z$ drugiej jednak strony, w poszczególnych organizacjach nieformalne zwyczaje i instytucje funkcjonują, pozwalają najsilniejszym państwom obchodzić delegowane kompetencje, np. w Mercosur decyzje są często rezultatem nieformalnej dyplomacji prezydenckiej, a nie wymogów formalnych procesu decyzyjnego. Podobnie w ASEAN dominuje nieformalne i przez consensus podejmowanie decyzji, chociaż reformy zwiększyły kompetencje sekretariatu oraz udział trzeciej strony w rozwiązywaniu sporów. Pomimo tego, można wyciągnąć ogólny wniosek z badań, że występuje trend, nierówny wśród organizacji, wyposażania przez państwa niezależnych od nich organów w dodatkowe funkcje i kompetencje (Lenz, Marks, s. 516).

Podsumowując, można zauważyć znaczące zróżnicowanie relacji między suwerennością a procesami integracji zachodzącymi w formie najbardziej zinstytucjonalizowanej, jaką są organizacje międzynarodowe. Z drugiej strony, Unia niewątpliwie wyróżnia się na tle innych międzynarodowych organizacji i instytucji integracyjnych. Można zauważyć, że Unia w licznych przypadkach była modelowym rozwiązaniem dla innych, przynajmniej na pierwszy rzut oka. Wiele organizacji integracyjnych ma podobne lub takie same organy, przynajmniej z nazwy. Natomiast w praktyce, ich skład, kompetencje i relacje do państw znacznie odbiegają od rozwiązań zastosowanych w UE. Przede wszystkim wszystkie organizacje w stosunku do Unii są na znacznie niższym poziomie w integracji, zazwyczaj wspólnego rynku, co może wpływać na zastosowane rozwiązania instytucjonalne. Ponadto nie obserwuje się u nich efektu rozprysku, który można zaobserwować w Europie. W organizacjach niezachodnich występuje też tendencja do podejmowania decyzji przez consensus, co jest najskuteczniejszą metodą zachowania niezależności w ramach organizacji. Z drugiej jednak strony występuje tendencja do rozszerzania kompetencji organizacji oraz podejmowania decyzji większością kwalifikowaną. Nie należy się spodziewać uniwersalizacji modelu europejskiego, nie tylko ze względu na różnice gospodarcze, społeczne czy kulturowe, ale również różnice w podejściu do suwerenności i jej zabezpieczenia w organizacjach międzynarodowych i procesach integracyjnych. $Z$ drugiej jednak strony nawet w konstrukcję UE są wbudowane środki i mechanizmy ochrony suwerenności, takie jak zasada kompetencji przyznanych, zasady proporcjonalności i pomocniczości, kontrola parlamentów i Trybunału Sprawiedliwości UE krajowym nad przekraczaniem przez organy Unii kompetencji a ostatecznie wystąpienie z organizacji. Generalnie rzecz biorąc, państwa dążą do 
ukształtowania optymalnego z punktu widzenia ich doświadczeń i interesów systemu instytucjonalnego, także, by zachować jak najszersze możliwości działania w procesach integracji i narastających współzależności.

\section{Bibliografia}

Acharya A. (2016), Regionalism beyond EU - Centrism, w: The Oxford Handbook of Comparative Regionalism, red. T. A. Borzel, T. Risse, Oxford University Press, Oxford.

Czaputowicz J. (2013), Suwerenność, Polski Instytut Spraw Międzynarodowych, Warszawa.

Czaputowicz J (2018), Teorie integracji europejskiej, Wydawnictwo Naukowe PWN, Warszawa.

Hawkins D. G., Lake D. A., Nielsen D. L., Tierney M. J. (2006), Delegation under Anarchy: States, International Organizations, and Principal-Agent Theory, w: Delegation and Agency in International Organizations, red. D. G. Hawkins, D. A. Lake, D. L. Nielsen, M. J. Tierney, Cambridge University Press, Cambridge.

Hoefnagels H. (1981), Growth of International Organizations since 1945: Interpretations of Quantitative and Qualitative Evidence, w: R. Jutte, A. Jutte, The Future of International Organizations, London.

Hoffmann S. (1966), Obstinate or Obsolete: The Fate of the Nation-State and the Case of Western Europe, „Daedalus”, nr 95.

Moon Ch. (2016), Economic regionalism, w: Encyclopaedia Britannica, http:www.britannica.com/ topic/economic-regionalism, 9.07.2020.

Juncker J.-C. (2018), Orędzie o stanie Unii 2018. Czas europejskiej suwerenności, https://www. elysee.fr/emmanuel-macron/2017/09/26/initiative-pour-1-europe-discours-d-emmanuelmacron-pour-une-europe-souveraine-unie-democratique, 23.06.2020.

Kaczyński P. M. (2019), O suwerenności narodowej i europejskiej, https://ec.europa.eu/polnad/ news/190509_kaczynski_suwerennosc_pl, 24.06.2020.

Keohane R., Hoffmann S., Institutional Change in Europe in the 1980s, w: The New European Community: Decisionmaking and Institutional Change, red. R. Keohane, S. Hoffmann, Westview Press, Boulder, CO.

Kranz J. (2013), Przekazanie kompetencji na rzecz organizacji międzynarodowej w świetle praktyki Polski, Niemiec i Francji, Wydział Prawa i Administracji, Uniwersytet Łódzki, Łódź.

Kranz J. (2015), Pojęcie suwerenności we wspótczesnym prawie międzynarodowym, Dom Wydawniczy Elipsa, Warszawa.

Lenz T., Marks G. (2016), Regional Institutional Design, w: The Oxford Handbook of Comparative Regionalism, red. T. A. Borzel, T. Risse, Oxford University Press, Oxford.

Macron E., Initiative pour l 'Europe Souveraine, Unie, Democratic, Paryż, 26 września 2017 r. https://www.elysee.fr/emmanuel-macron/2017/09/26/initiative-pour-l-europe-discours-demmanuel-macron-pour-une-europe-souveraine-unie-democratique, 23.06.2020.

Menkes J., Wasilkowski A. (2017), Organizacje międzynarodowe. Prawo instytucjonalne, Wydawnictwo Naukowe PWN, Warszawa.

Mitrany D. (1975), The Functional Theory of Politics, L, London.

Mitrany D. (1966), A Working Peace System, Quadrangle Books, Chicago.

Moon Ch. (2016), Economic regionalism, w: Encyclopaedia Britannica, http:www.britannica.com/ topic/economic-regionalism, 9.07.2020.

Popiuk-Rysińska I. (1993), Suwerenność w rozwoju stosunków międzynarodowych, Dom Wydawniczy i Handlowy „ELIPSA”, Warszawa. 
Popiuk-Rysińska I. (1995), Suwerenność współczesnych państw - konieczność redefinicji, w: Państwo we wspótczesnych stosunkach międzynarodowych, red. E. Haliżak, I. Popiuk-Rysińska, Wydawnictwo Naukowe Scholar, Warszawa.

Ruszkowski J. (2010), Ponadnarodowość w systemie politycznym Unii Europejskiej, Oficyna, Warszawa.

Traktat o Unii Europejskiej, https://eur-lex.europa.eu/legal-content/PL/TXT/?uri=uriserv:OJ.C_. 2012.326.01.0001.01.POL\&toc=OJ:C:2012:326:TOC\#C_2012326PL.01001301.

\section{Streszczenie}

Artykuł wpisuje się w nurt badań dotyczących suwerenności państw w międzynarodowych organizacjach integracyjnych, w których uczestnictwo wiąże się z największymi ograniczeniami w zakresie kompetencji i autonomii państw, w porównaniu z udziałem w innego typu organizacjach. Zostaje wyjaśnione pojęcie suwerenności, zwracając uwagę na jej wymiar prawny i polityczny, jak również międzynarodowej organizacji integracyjnej, która występuje tylko w grupie organizacji regionalnych. Artykuł zawiera analizę zróżnicowanego, z punktu widzenia suwerenności, usytuowania państw w organizacjach integracyjnych, w których stosowane są nowego typu rozwiązania instytucjonalne, w tym ponadnarodowe. Badania odnotowują znaczące zróżnicowanie rozwiązań instytucjonalnych, pokazujące, że modele zastosowane w Europie nie znajdują uniwersalnego zastosowania. Widoczne jest odmienne podejście do suwerenności w procesach integracyjnych i organizacjach międzynarodowych na Zachodzie oraz wśród państw rozwijających się, które większą wagę przywiązują do ochrony i zabezpieczenia suwerenności w ramach organizacji.

Słowa kluczowe: suwerenność, integracja, organizacja międzynarodowa, regionalizm, Unia Europejska

\section{Sovereignty of States in International Integration Organizations}

\section{Summary}

This article is one of many, which deal with research on state sovereignty in international integration organizations, where participation implies more limited autonomy and competition than in organizations of other types. The notion of sovereignty is being explained, pointing at its legal and political dimention, as well as of international integration organizations, which belong to a group of regional organizations only. This paper concerns the analysis of differentiated placement of states from sosvereignty point of view in the integration organizations, where new instruments have been implemented, including transnational ones. The research shows a considerable differentiation of institutional frameworks, meaning that their models introduced in Europe have no universal character. One can see different attitude towards the sovereignty notion in integration processes and in international organizations in the West as well as in developing countries, which focus mostly on sovereignty protection within the organization itself.

Key words: sovereignty integration, international organization, regionalism, European Union 
